\title{
Magnetic Nanoparticles based on Natural Silica as a Methyl Ester Forming Acid Catalyst
}

\author{
Falah Azizah EImaria ${ }^{1,2}$ and S. N. Aisyiyah Jenie ${ }^{2 *}$ \\ ${ }^{1}$ Department of Chemistry, Faculty of Science and Technology, Islamic State University of Syarif Hidayatullah, \\ Ir. H. Juanda Street 96, Ciputat, South Tangerang, 15314 Indonesia \\ ${ }^{2}$ Research Center for Chemistry, Indonesian Institute of Sciences, Building 452, Kawasan Puspiptek, Serpong, \\ South Tangerang, Banten 15314 Indonesia
}

*Corresponding author: siti045@lipi.go.id

\begin{tabular}{|c|c|}
\hline ARTICLE INFO & Abstract \\
\hline $\begin{array}{l}\text { Article History: } \\
\text { Received date: } 02 \text { May } 2021 \\
\text { Revised date: } 20 \text { September } 2021 \\
\text { Accepted date: } 21 \text { October } 2021 \\
\text { Available online at: November } 2021\end{array}$ & \multirow{2}{*}{ 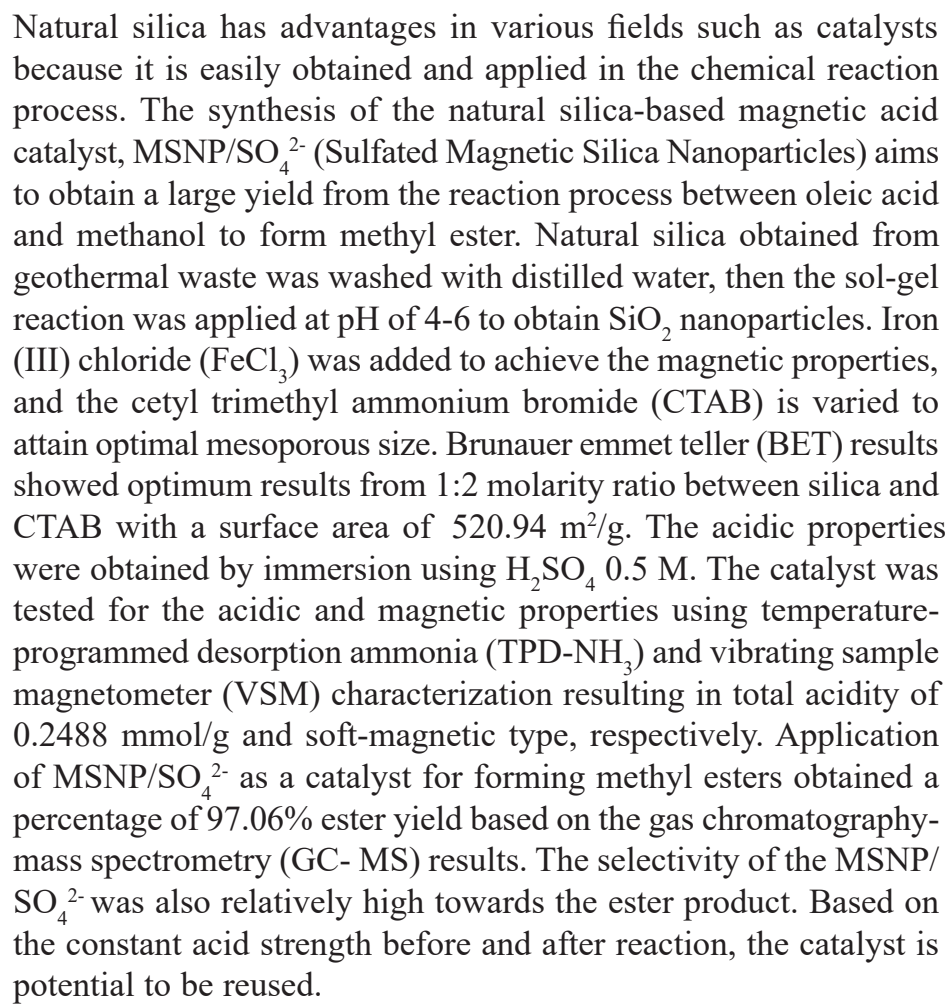 } \\
\hline $\begin{array}{l}\text { Keywords: } \\
\text { Acid catalyst, magnetic nanoparticle, } \\
\text { methyl ester, sol gel, natural silica. }\end{array}$ & \\
\hline & $\begin{array}{l}\text { (C) } 2021 \text { Jurnal Kimia Terapan Indonesia. This is an open access article } \\
\text { under the CC BY-NC-SA license (https://creativecommons.org/licenses/ } \\
\text { by-nc-sa/4.0/). }\end{array}$ \\
\hline
\end{tabular}

\section{INTRODUCTION}

Silica is an inorganic material that is abundantly available in nature. The synthesis of silica can be conducted by utilizing geothermal sludge as the precursor using the sol-gel method [1]. Silica generated using the sol-gel method has been initiated since 1968 by Stober, where hydrolysiscondensation reactions of silica oxide or halide gel resulted in a polymer system (silica gel) forming the so-called xerogel [2].

Magnetite oxide $\left(\mathrm{Fe}_{2} \mathrm{O}_{3}\right.$ or $\left.\mathrm{Fe}_{3} \mathrm{O}_{4}\right)$ has much potential as an additive in applications such as in pigmentation, as environment absorber, catalyst and photocatalyst. Using magnetic heterogeneous catalyst has much potential due to the strong acid strength and is readily separable from the 
product [3]. Silica magnetite can be obtained by two approaches, the encapsulation of iron oxide into silica shell and the immobilization of nanoparticles into silica surface using sol-gel method [4]. The benefit of using magnetic silica nanoparticles (MSNP) can produce stabilization for magnetite $\left(\mathrm{Fe}_{3} \mathrm{O}_{4}\right)$ hence prevent it to be easily oxidized and increasing the performance of magnetite [5].

The formation of magnetic silica nanoparticles pores can be obtained by the use of surfactants, such as CTAB. Previous study has used the CTAB surfactant as a template to synthesize mesoporous tetraethyl orthosilicate (TEOS)-based catalyst. With a TEOS and CTAB molarity ratio of 1:4 resulted in a surface area of the catalyst of $469 \mathrm{~m}^{2} / \mathrm{g}$ compared to that without CTAB of $118 \mathrm{~m}^{2} / \mathrm{g}$ [6]. Another study showed that magnetic mesoporous silica nanoparticles using CTAB and TEOS as the precursor generated a surface area of $78.319 \mathrm{~m}^{2} / \mathrm{g}$ with a particle size of $7.44 \mathrm{~nm}$ [7]. To generate the heterogeneous acid catalyst, sulfonation or sulfated method may be applied for the mesoporous material. A study on the sulfated method has been reported which utilized $5 \mathrm{~g}$ of $\mathrm{ZrO}_{2}$-bentonite $/ \mathrm{SO}_{4}^{2-}$ immersed in $75 \mathrm{~mL}$ of 0.5 $\mathrm{M} \mathrm{H}_{2} \mathrm{SO}_{4} 0.5 \mathrm{M}$ for $24 \mathrm{~h}$ to maintain acidity [8].

In this research, we report the synthesis dan characterization of magnetic silica nanoparticles (MSNP) its sulfated form ( $\mathrm{MSNP} / \mathrm{SO}_{4}{ }^{2-}$ ) derived from geothermal silica sludge. The nanoparticles were modified from iron salt and CTAB via the sol-gel method and modified by sulfuric acid to obtain the acid catalyst. Iron oxide was applied to obtain the magnetic material while CTAB was applied to obtain the mesoporous structure. The MSNP was characterized using BET, TPD$\mathrm{NH}_{3}$, and VSM. The catalyst based on sulfated magnetic silica nanoparticles was applied for the esterification of methanol and oleic acid whereas it was expected to provide a high percentage of total methyl esters observed using GC-MS.

\section{EXPERIMENTAL SECTION}

\subsection{Materials}

Geothermal sludge was obtained from the geothermal power plant (PT Geodipa Energy, Dieng, Central Java), sodium hydroxide
$(\mathrm{NaOH})$, hydrochloric acid $(\mathrm{HCl})$, ferric chloride hexahydrate $\left(\mathrm{FeCl}_{3} \cdot 6 \mathrm{H}_{2} \mathrm{O}\right)$, cetyl trimethylammonium bromide (CTAB), oleic acid, methanol $\left(\mathrm{CH}_{3} \mathrm{CH}_{2} \mathrm{OH}\right)$ and sulfuric acid $\left(\mathrm{H}_{2} \mathrm{SO}_{4}\right)$ were provided from Merck.

\subsection{Synthesis of MSNP}

A total of $10 \mathrm{~g}$ of dry silica was added to $400 \mathrm{~mL}$ of $1.5 \mathrm{~N} \mathrm{NaOH}$, then mixed, homogenized, and heated at $90^{\circ} \mathrm{C}$ for $1 \mathrm{~h}$. Subsequently, the mixture was filtered and the filtrate was taken. The formed $\mathrm{Na}_{2} \mathrm{SiO}_{3}$ was added with $5 \mathrm{~g} \mathrm{FeCl}_{3} \cdot 6 \mathrm{H}_{2} \mathrm{O}$, and $\mathrm{HCl} 2 \mathrm{~N}$ to form a gel and added variations of CTAB $0 ; 0.2 ; 0.4 ; 0.6 ; 0.8$ and $1.0 \mathrm{M}$ for $18 \mathrm{~h}$, washed using aquadest to neutral $\mathrm{pH}$, filtered, the residue was taken and dried in the oven, annealed at $600^{\circ} \mathrm{C}$, for $8 \mathrm{~h}[2,9,6]$. The MSNP samples were analyzed by surface area analysis using BET method and the optimized MSNP was analyzed by VSM.

Tabel 1. Sample Codes of MSNP

\begin{tabular}{ccc}
\hline \multirow{2}{*}{ Sample Code } & \multicolumn{2}{c}{ Molar } \\
\cline { 2 - 3 } & CTAB & SiO2 \\
\hline MSNP0 & 0 & 1 \\
MSNP1 & 1 & 1 \\
MSNP2 & 2 & 1 \\
MSNP3 & 3 & 1 \\
MSNP4 & 4 & 1 \\
MSNP5 & 5 & 1 \\
\hline
\end{tabular}

\subsection{Modification of MSNP}

A total of $5 \mathrm{~g}$ of MSNP was mixed with $75 \mathrm{~mL}$ $\mathrm{H}_{2} \mathrm{SO}_{4} 0.5 \mathrm{M}$. The mixture was homogenized for $24 \mathrm{~h}$, filtered, dried overnight. The formed $\mathrm{MSNP} / \mathrm{SO}_{4}^{2-}$ was added to methanol and oleic Acid 1:8 vol/vol. The reaction was under reflux and homogenized at $60^{\circ} \mathrm{C}$ for 60 minutes, then separated [8]. The result of $\mathrm{MSNP} / \mathrm{SO}_{4}{ }^{2-}$ was analyzed by TPD-NH3 for its acidity.

\subsection{Application of $\mathrm{MSNP} / \mathrm{SO}_{4}{ }^{2-}$}

A total of $\mathrm{MSNP} / \mathrm{SO}_{4}{ }^{2-} 3 \%$ was added in solution from oleic acid and methanol with volume ratio 
of $1: 8$. Condensation of the mixture at $60^{\circ} \mathrm{C}$ for 60 minutes. The result of total percentage of changes oleic acid converted into methyl ester was analyzed by GC-MS $[10,11]$. The conversion of yield and selectivity of methyl ester were calculated to use the following equations, respectively.

\subsection{Characterization}

Brunauer-Emmett-Teller (BET) analysis of the MSNP samples was conducted using Tristar II 3020 Micromeritics Instrument (USA) to obtain the specific surface area, pore volume, and pore size of the samples through nitrogen adsorptiondesorption isotherms, performing at $77.3^{\circ} \mathrm{K}$ on a liquid nitrogen apparatus after degassing the sample at $110^{\circ} \mathrm{C}$ for $6 \mathrm{~h}$.

The saturation magnetization and the surface magnetic field of the MSNP sample were performed to use a Vibrating Sample Magnetometer (VSM 250 Dexing Magnet Ltd).

$\mathrm{NH}_{3}$-Temperature Programmed-Desorption (NH3-TPD) of $\mathrm{MSNP} / \mathrm{SO}_{4}{ }^{2-}$ samples were performed using Micromeritics ChemiSorb 2750 Pulse Chemisorption System (USA). The analysis was carried out of Helium (He) gas of $10 \mathrm{~mL} /$ min. After each TPD measurement, the amount of ammonia adsorbed was determined from the calibration curve obtained from varying volumes of ammonia in He, the total acidities of MSNP/ $\mathrm{SO}_{4}^{2-}$ samples were measured by comparing the $\mathrm{NH}_{3}$-TPD spectra to that of the reference material.

Gas Chromatography Mass Spectrometry (GC-MS) of the raw material and esterification product ware carried out on Agilent 19019S (Germany), column HP-5MS, $30 \mathrm{~m} \times 250 \mu \mathrm{m}$, $0.25 \mu \mathrm{m}$.

\section{RESULT AND DISCUSSION}

\subsection{Synthesis of MSNP and MSNP/SO ${ }_{4}{ }^{2-}$}

The MSNP investigated in this study was based on the natural silica from geothermal waste. This geothermal silica, which is the side product of a geothermal plant, is used as the precursor for the fabrication of silica-based magnetic silica nanoparticles using the common approach of the sol-gel process [1]. The $\mathrm{MSNP} / \mathrm{SO}_{4}{ }^{2-}$ was generated by modifying MSNP with sulfuric acid.

The mechanism of the formation of MSNP and subsequently $\mathrm{MSNP} / \mathrm{SO}_{4}{ }^{2-}$ is shown in Figure 1.

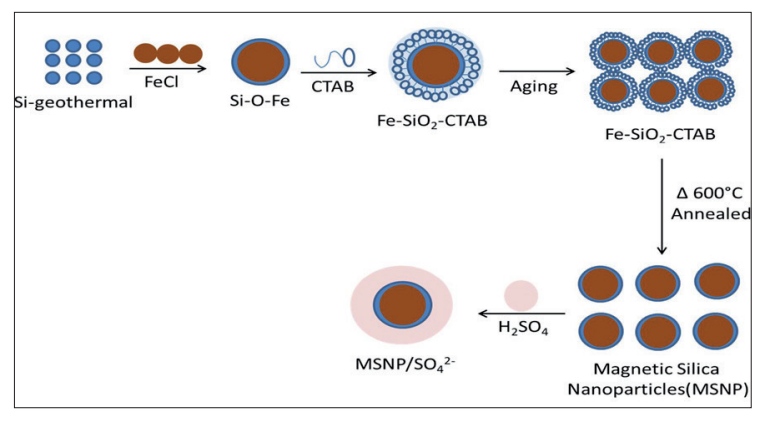

Figure 1. The synthesis of MSNP and $\mathrm{MSNP} / \mathrm{SO}_{4}^{2-}$

Figure 1 shows the synthetic mechanism of the sulfated magnetic silica nanoparticles (MSNP/ $\mathrm{SO}_{4}^{2-}$ ). The geothermal silica (Si-geothermal), which was washed and dried prior to use, was applied as the precursor to form sodium silicate $\left(\mathrm{Na}_{2} \mathrm{SiO}_{3}\right)$. The sodium silicate was subsequently added with $\mathrm{FeCl}_{3}$, forming the $\mathrm{Si}-\mathrm{O}-\mathrm{Fe}$, in which the silica $(\mathrm{Si})$ would coat the iron $(\mathrm{Fe})$ molecules. In this study, the presence of silanol groups on the silica surface can be modified with various functional groups [5]. The mixture was then added with $\mathrm{HCl}$ and $\mathrm{CTAB}$ to form $\mathrm{Fe}-\mathrm{SiO}_{2}-\mathrm{CTAB}$. The CTAB was the template, which was varied to obtain the optimized mesoporous structure of the nanoparticle. The $\mathrm{Fe}-\mathrm{SiO}_{2}-\mathrm{CTAB}$ underwent aging for $18 \mathrm{~h}$ at room temperature, followed by annealing to remove the impurities such as surfactant and water molecules. In this study, the mesoporous silica nanoparticles with the highest specific surface area can be successfully obtained through the sol-gel process and the template method [6].

The modified $\mathrm{MSNP} / \mathrm{SO}_{4}{ }_{4}^{2-}$ was obtained by reacting MSNP with sulfuric acid $\left(\mathrm{H}_{2} \mathrm{SO}_{4}\right)$ at room temperature overnight. The $\mathrm{MSNP} / \mathrm{SO}_{4}{ }^{2-}$ had contained acid functional sites such as $-\mathrm{OH}$ (silanol group from silica) as a weak acid and $-\mathrm{SO}_{3} \mathrm{H}$ (sulfate group from sulfuric acid) as strong acid [11]. The $\mathrm{MSNP} / \mathrm{SO}_{4}{ }^{2-}$ samples were further applied as heterogeneous catalyst in an esterification reaction. 


\subsection{Characterization of Magnetic Silica Nanoparticles (MSNP)}

The characteristics of the magnetic silica nanoparticles were presented in Table 2 and Figure 2.

Tabel 2. Surface area analysis of MSNP

\begin{tabular}{cccc}
\hline $\begin{array}{c}\text { Sample } \\
\text { Code }\end{array}$ & $\begin{array}{c}\text { Surface } \\
\text { Area } \\
(\mathrm{m} 2 / \mathrm{g})\end{array}$ & $\begin{array}{c}\text { Pore } \\
\text { Volume } \\
(\mathrm{cm} 3 / \mathrm{g})\end{array}$ & $\begin{array}{c}\text { Size } \\
(\mathbf{n m})\end{array}$ \\
\hline MSNP0 & 238.50 & 0.8003 & 25.157 \\
\hline MSNP1 & 490.81 & 1.2911 & 12.225 \\
\hline MSNP2 & 520.94 & 1.5970 & 11.518 \\
\hline MSNP3 & 406.88 & 1.1205 & 14.746 \\
\hline MSNP4 & 308.56 & 1.2543 & 19.445 \\
MSNP5 & 241.58 & 0.2580 & 24.836 \\
\hline
\end{tabular}

Table 2 showed that at CTAB concentration of $2 \mathrm{M}$ the optimum surface area of the MSNP was generated of $520.94 \mathrm{~m}^{2} / \mathrm{g}$. The surface area was affected by the pore volume and particle size, the larger the surface area, the lower its nanoparticle size. Using CTAB over than optimum result, i.e. MSNP3, MSNP4 and MSNP5 would enlarge the pore volume leading to the collapse of the porous structure of the material and the decrease surface area [12]. This result was higher than that studied by Loryuenyong, et al.[6]

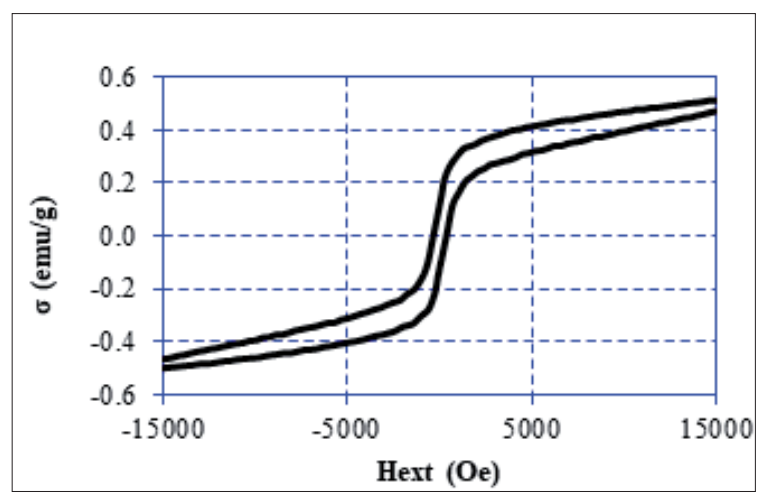

Figure 2. Sample Hysterical Curve of MSNP

The magnetic properties of MSNP2 as the optimized nanoparticle was examined by VSM. The hysteresis loop of MSNP2 is shown in Figure 2. It showed that the maximum magnetization from the examination of MSNP2 was 0.54 $\mathrm{emu} / \mathrm{g}$ and exhibits a low remanence magnetization value. The result showed that MSNP2 had soft-magnetic characteristics. The soft-magnetic characteristic was due to the higher concentration of $\mathrm{SiO}_{2}$ than that of iron $[11,13,14]$.

\subsection{Application of Sulfated Magnetic Silica Nanoparticles (MSNP/SO ${ }_{4}{ }^{2-}$ )}

The result of MSNP optimum (MSNP2) was further modified to form acid catalyst, by adding sulfuric acid-generating $\mathrm{MSNP} / \mathrm{SO}_{4}{ }^{2-}$. The catalyst would be used for the esterification of oleic acid and methanol. The products of esterification were presented in Table 3.

Tabel 3. The Result of GC-MS : The Product of Esterification from Oleic Acid and Methanol

\begin{tabular}{|c|c|c|c|c|c|}
\hline No. Peak & Retention Time & Chemical Compound & $\begin{array}{l}\text { Molecular } \\
\text { Weight (g/ } \\
\text { mol) }\end{array}$ & $\begin{array}{l}\text { Relative Com- } \\
\text { pound }(\%)\end{array}$ & $\begin{array}{l}\text { Chemical } \\
\text { Formula }\end{array}$ \\
\hline 1. & 18.371 & $\begin{array}{l}\text { Hexadecanoic acid, methyl } \\
\text { ester (Methyl Palmitate) }\end{array}$ & 270.46 & 1.53 & $\mathrm{C} 17 \mathrm{H} 34 \mathrm{O} 2$ \\
\hline 2. & 19.996 & $\begin{array}{l}\text { 9,12-Octadecadienoic acid } \\
\text { (Z,Z)-, methyl ester (Methyl } \\
\text { Linoleate) }\end{array}$ & 294.47 & 10.20 & $\mathrm{C} 19 \mathrm{H} 34 \mathrm{O} 2$ \\
\hline 3. & 20.072 & $\begin{array}{l}\text { 9- Octadecanoic acid } \\
\text { (Z)-, methyl ester (Methyl } \\
\text { Oleate) }\end{array}$ & 296.49 & 85.41 & $\mathrm{C} 19 \mathrm{H} 36 \mathrm{O} 2$ \\
\hline 4. & 20.261 & Methyl Stearate & 298.51 & 2.85 & $\mathrm{C} 19 \mathrm{H} 38 \mathrm{O} 2$ \\
\hline
\end{tabular}


Table 3 showed that the product of the reaction was 9,12-octadecadienoic acid (Z, Z)-, methyl ester with a relative yield of $97.06 \%$ and selectivity of $85.41 \%$. This confirms the esterification reaction has been successful using the MSNP/ $\mathrm{SO}_{4}{ }^{2-}$ catalyst. The analysis showed that no reactant (e.g. oleic acid) was in the product, confirming the high obtained yield. The reaction between oleic acid and methanol produced $1.53 \%$ methyl palmitate, $10.2 \%$ methyl linoleate, methyl oleate, and $2.85 \%$ methyl stearate. This indicates the high selectivity of catalyst MSNP/ $\mathrm{SO}_{4}{ }^{2-}$ towards the ester product.

\subsection{Characterization of the catalyst of Sulfated Magnetic Silica Nanoparticles (MSNP/SO ${ }_{4}{ }^{2-}$ )}

The acidity of the MSNP/ $\mathrm{SO}_{4}{ }^{2-}$ catalyst before and after esterification reaction is shown in Table 4.

Table 4. TPD-NH $\mathrm{NH}_{3}$ : Before and After Esterification Reaction

\begin{tabular}{lllll}
\hline Sample & $\begin{array}{l}\text { Total of } \\
\text { sample } \\
\text { (g) }\end{array}$ & $\begin{array}{l}\text { Surface } \\
\text { area of } \\
\text { analysis }\end{array}$ & $\begin{array}{l}\text { Mol } \\
\mathbf{N H 3} \\
(\mathrm{mmol})\end{array}$ & $\begin{array}{l}\text { Acidity, } \\
\mathrm{mmol} / \mathrm{g}\end{array}$ \\
\hline $\begin{array}{l}\text { Before } \\
\text { reaction }\end{array}$ & 0.0306 & 0.2307 & $\begin{array}{l}7.6131 \\
\times\end{array}$ & 0.2488 \\
$\begin{array}{l}\text { After } \\
\text { reaction }\end{array}$ & 0.0324 & 0.2324 & $\begin{array}{l}7.6692 \\
\times\end{array}$ & 0.2367 \\
\hline
\end{tabular}

The MSNP/ $/ \mathrm{SO}_{4}{ }^{2-}$ was further tested for acidity to observe the reusability. Table 4 showed acid yield for the $\mathrm{MSNP} / \mathrm{SO}_{4}{ }_{4}^{2-}$ before the reaction was $0.2488 \mathrm{mmol} / \mathrm{g}$ and after the reaction was 0.2367 $\mathrm{mmol} / \mathrm{g}$. The $0.0212 \mathrm{mmol} / \mathrm{g}$ difference in the acidity of the $\mathrm{MSNP} / \mathrm{SO}_{4}{ }^{2-}$ before and after was significantly low, hence the acidity is relatively constant and the $\mathrm{MSNP} / \mathrm{SO}_{4}{ }^{2-}$ catalyst could be reused. The acid site on the $\mathrm{MSNP} / \mathrm{SO}_{4}{ }^{2-}$ catalyst resulted from sulfuric and also from silica and iron [15].

The result of the optimized MSNP was modified into sulfated magnetic silica nanoparticles (MSNP/ $\mathrm{SO}_{4}{ }^{2-}$ ). The magnetic properties of MSNP had soft magnetic characteristics with surface area of $520.94 \mathrm{~m}^{2} / \mathrm{g}$. The acidity of the MSNP/ $\mathrm{SO}_{4}{ }^{2-}$ catalyst was $0.2488 \mathrm{mmol} / \mathrm{g}$. The MSNP/
$\mathrm{SO}_{4}^{2-}$ was applied as heterogenous acid catalyst in the esterification reaction between oleic acid and methanol with calculated ester yield of $85.41 \%$.

\section{CONCLUSIONS}

We have synthesized magnetic silica nanoparticles which were subsequently modified with sulfuric acid. The modified nanoparticle was used as a heterogeneous acid catalyst on esterification reaction of oleic acid and methanol. The catalyst was mesoporous due to the different concentrations of CTAB. The characterization was confirmed by surface area analysis using BET method and magnetic characterization using VSM. A total of $3 \%$ of $\mathrm{MSNP} / \mathrm{SO}_{4}{ }^{2-}$ was used reaction mixture which resulted in $97.06 \%$ ester yield. The selectivity of the $\mathrm{MSNP} / \mathrm{SO}_{4}{ }^{2-}$ was also relatively high towards the ester product. Based on the constant acid strength before and after reaction, the catalyst can be reused. The result from this work can open new opportunities for the development of magnetic silica nanoparticles catalyst from natural-based silica.

\section{ACKNOWLEDGMENT}

The authors would like to acknowledge the Research Center for Chemistry for the funding. This research was also funded by JFS SEA-EU/LPDP NAPARBA Project Grant No. SEAEUROPEJFS19ST-117. SNAJ is the main contributor.

\section{REFERENCES}

[1] Jenie SNA, Ghaisani A, Ningrum YP, Kristiani A. "Preparation of silica nanoparticles from geothermal sludge via sol-gel method," presented at 2nd Int. Conf. on Chemistry, Chemical Prosess and Enngineering, Yogyakarta, Indonesia, 2018.

[2] Osman NS, Sapawe N. "Optimization of silica $\left(\mathrm{SiO}_{2}\right)$ synthesis from acid leached oil palm frond ash (OPFA) through sol-gel method," Materials Today: Proceedings, 2020, pp. 1-6.

[3] Liu Wu-Jun, Tian Kei, Jiang Hong, Yu HanQing. "Facile synthesis of highly efficient and recylable magnetic solid acid from biomass waste," Sci Rep, 2013, pp. 2419-2426.

[4] Cendrowski K, Sikora P, Zielinska B, Horszczaruk E. "Chemical and thermal stability of core-shelled magnetite nanoparticles and solid silica,” Appl Surf Sci, 2017, pp. 391-397. 
[5] Amaria, Suyanta, Nuryono. "Coating of L-arginine modified silica on magnetite through two different sol-gel routes". Indonesian J. Chem, 2017, vol. 17(2), pp. 256-263.

[6] Loryuenyong V, Muanghom T, Apinyanukul T, Rutthongjan P. "Synthesis of templated mesoporous silica nanoparticles under base catalysis," Advances in Appl. Ceramaics, 2011, vol. 110(6), pp. 335-339.

[7] Tavakoli Z, Rasekh B, Yazdian F, Maghsoudi A. "One-step separation of the recombinant protein by using the amine- functionalized magnetic mesoporous silica nanoparticles; an efficient and facile approach," Int. J. Biol. Macromol, 2019, pp. 600-608.

[8] Ruslan, Hardi J, Mirzan M. (2017, Oktober). "Sintesis dan karakterisasi katalis lempung terpilar zirkonia tersulfatasi sebagai katalis perengkah," Prosiding Seminar Nasional Kimia UNY, pp. 325-334.

[9] Barrabino A. "Synthesis of mesoporous silica particles with control of both pore diameter and particle size". Master of Science Thesis, Chalmers University of Thechnology, Sweden, 2011.

[10] Prihantoro S, Prasetyoko D. "Katalis silika tersulfat dari kaolin bangka belitung untuk esterifikasi asam oleat dengan metanol," J. Sains dan Seni Pomits, 2014, vol. 1(1), pp. 1-5.
[11] Jenie SNA, Kristiani A, Simanungkalit SP, Mansur D. (November, 2017). "Preparation of nanobiochar as magnetic solid acid catalyst by pyrolysis- carbonization from oil palm empty fruit bunches". Procc. Of the 3rd Int. Symposium on Appl. Chemistry, 2017.

[12] Dong Y, Zhang W, Tao Y. "CTAB modified $\mathrm{TiO}_{2}$ supported on HZSM-5 zeolite for enhanced photocatalytic degradation of azophloxine," J. Materials Research and Tech, 2020, vol. 9(4), pp. 9403-9411.

[13] Taib S, Suharyadi E. "Sintesis nanopartikel magnetite $\left(\mathrm{Fe}_{3} \mathrm{O}_{4}\right)$ dengan template silika $\left(\mathrm{SiO}_{2}\right)$ dan karakterisasi sifat," Indonesian J. Appl. Physics, 2015, vol 5(1), pp. 23-30.

[14] Bruzamarello N, Cardoso S, Luiz F, Vitali L, Luis A. "Magnetic solid-phase extraction of triclosan from water using $\mathrm{n}$-octadecyl modi fi ed silica-coated magnetic nanoparticles," J. Environ Chem Eng, 2020, vol. 8(4), pp. 1-11.

[15] Mosallanejad S, Dlugogorski ZB, Kennedy ME, Stockenhuber M. "On the chemistry of iron oxide supported on $\gamma$-alumina and silica catalysts," American Chem. Sosiety Omega, 2018, pp. 5362-5374. 